\title{
A Double FDG/PET Study of the Effects of Scopolamine in Older Adults
}

\author{
Susan E. Molchan, M.D., John A. Matochik, Ph.D., Alan J. Zametkin, M.D., \\ Herman V. Szymanski, M.D., Marc Cantillon, M.D., \\ Robert M. Cohen, M.D., Ph.D., and Trey Sunderland, M.D.
}

Two consecutive positron emission scans were done in one session using a double injection method of $\left[{ }^{18} \mathrm{~F}\right] 2$ fluoro-2-deoxyglucose administration to examine the effects of the antimuscarinic drug scopolamine on cerebral glucose metabolism in ten older adults. Scopolamine causes temporary memory impairment, and its effects have been used to model aspects of the cognitive impairment that occur in Alzheimer's disease (AD). Cortical metabolic rates of patients with $A D$ have been reported to be depressed, especially in parietal, temporal, and frontal association areas. After scopolamine administration to the elderly volunteers, absolute and normalized glucose metabolic rates were depressed in prefrontal and occipital regions and increased in parietaloccipital cortical regions and a left middle temporal region. These changes in the older volunteers are generally not consistent with changes seen in $A D$. We conclude that deficits in muscarinic system function may contribute to some but not all of the hypometabolic changes seen in $A D$ patients.

[Neuropsychopharmacology 10:191-198, 1994]
KEY WORDS: Memory; Scopolamine; Alzheimer's disease; 18-Fluoro-2-deoxy-2-D-glucose; Positron emission tomography

The anticholinergic drug scopolamine causes temporary memory impairment and has been used to explore the role of the muscarinic cholinergic system in memory processes in both animals and humans (Drachman and Leavitt 1974; Bartus et al. 1982; Kopelman and Corn 1988; Molchan et al. 1992). It has been used to model

From the Section on Geriatric Psychiatry (SEM, MC, TS), Laboratory of Clinical Science, the Section on Clinical Brain Imaging (JAM, AJZ, RMC), Laboratory of Cerebral Metabolism, National Institute of Mental Health, Bethesda, Maryland, and the Department of Psychiatry (HVS), Veterans Administration Medical Center, Buffalo, New York.

Address correspondence to Susan Molchan, M.D., NIH Clinical Center, 9000 Rockville Pike, Bldg. 10, Room 3D41, Bethesda, Maryland 20892.

Received June 25, 1993; revised January 12, 1994; accepted January 24, 1994. aspects of the memory impairment that occurs in normal aging (Drachman and Leavitt 1974; Molchan et al. 1992) and Alzheimer's disease (AD) (Sunderland et al. 1986; Molchan et al. 1992, for review). The pathological changes in the muscarinic cholinergic system of patients with $\mathrm{AD}$ are thought to contribute to the severe memory impairment that occurs in this disease (Davies and Maloney 1976; Perry et al. 1978; Bartus et al. 1982; Whitehouse et al. 1982). Patients with AD have been shown to have decreased cerebral blood flow (CBF) and metabolic rates in the cerebral cortex, with the greatest reductions in parietotemporal regions, and with more frontal involvement later in the disease process (Frackowiak et al. 1981; Foster et al. 1983; Haxby et al. 1988; Friedland et al. 1989; Kumar et al. 1991). It is unknown what neuropathological changes in the brain relate to the decreases in metabolic rate. In this study, using $\left({ }^{18} \mathrm{~F}\right)$ 2-fluoro-2-deoxy-D-glucose (FDG) in a double injection paradigm, we sought to explore whether metabolic rate patterns after acute scopolamine administration in older adults were analogous to patterns seen in unmedicated $\mathrm{AD}$ patients. 
Many studies have utilized positron emission tomography (PET) to explore the effects of psychoactive medications in various patient and normal control groups (Sedvall et al. 1986; Honer et al. 1988; Frey et al. 1992; Gitelman and Prohovnik 1992). Most prior PET studies though, in looking at effects before and after medication, have done so on different days. This is necessary for examining drugs such as tricyclic antidepressants, which may take weeks to induce their therapeutic effects. When studying the acute effects of a drug, scanning subjects before and after drug administration in the same session is likely to improve sensitivity. This is because variability is decreased when the subject does not have to be repositioned in the scanner (Phelps et al. 1984; Bartlett et al. 1988), when possible state changes across a long span of time are avoided, and when each subject serves as his or her own control (Phelps et al. 1984). In this study, we used a double injection paradigm (Brooks et al. 1987; Chang et al. 1987) using $\left({ }^{18} \mathrm{~F}\right)$ 2-fluoro-2-deoxy-D-glucose (FDG) to explore the acute metabolic effects of scopolamine in a group of older normal volunteers.

\section{METHODS}

This study was approved by the Internal Review Board of the National Institute of Mental Health and the Radiation Safety Committee of the National Institutes of Health. Informed consent was obtained from all subjects.

\section{Subjects}

Ten older normal volunteers (Table 1) participated in the study after informed consent and screening to exclude medical and psychiatric illness and family history of dementia or other neuropsychiatric disease. Their evaluation consisted of physical and mental status examinations, electrocardiogram, MRI scan of the brain, and laboratory tests for hematologic, hepatic, renal, and thyroid function. They also completed a battery of neuropsychological tests, which included the Wechsler Memory Scale-Revised (WMS-R) (Wechsler 1987), to ensure normal memory and other cognitive function. They were paid for their participation and were drugfree for at least three weeks prior to the study.

Table 1. Demographic Data on Ten Normal Volunteers

\begin{tabular}{lr}
\hline & Mean \pm SD \\
\hline Age (years) & $62.8 \pm 8.8$ \\
Education (years) & $17.6 \pm 2.6$ \\
Wechsler Memory Scale & $125.7 \pm 10.8$ \\
Weight (kg) & $69.4 \pm 15.0$ \\
Gender: 5F, 5M & \\
\hline
\end{tabular}

\section{PET Scan Procedure}

Subjects were fasting, and remained supine with eyes and ears uncovered throughout the scans, including the transmission scan, which was used to calculate attenuation. The scanner (Scanditronix, Essex, MA) has a full-width half-maximum in plane resolution of 5 to $6 \mathrm{~mm}$ and a $\mathrm{z}$-axis resolution of $11.8 \mathrm{~mm}$. Blood samples from the radial artery were obtained to calculate the tracer input curve. Subjects were free to open and close their eyes; the room was quiet, and no cognitive tasks were done. Each was fitted with a plastic hexalite face mask, which was fixed to the scanner headrest.

The first FDG injection ( 3.0 millicuries or $111 \mathrm{MBq}$ ) was administered at time 0 through an indwelling intravenous line; this was followed by a 30 minute uptake period. Emission scanning then commenced for 30 minutes. After completion of the first emission scan, $0.5 \mathrm{mg}$ of scopolamine hydrobromide was given intravenously over one minute. Thirty minutes later (within the 110 minute half-life of the first injection), the second FDG injection (5 millicuries or $185 \mathrm{MBq}$ ) was administered. As for the first scan, emission scanning followed a 30 minute uptake period (Figure 1). The residual radioactivity from the first injection was measured and subtracted from the counts measured during the second scan. The method used for this correction is based on an estimate of $k 4$, which is the dephosphorylation rate of FDG and the rate of decay of ${ }^{18} \mathrm{~F}$ (Brooks et al. 1987).

The dose of scopolamine was chosen based on a prior study of a range of doses which showed that a statistically significant decline in cognitive test performance in older volunteers occurred at the $0.5 \mathrm{mg}$ dose (Sunderland et al. 1986; Molchan et al. 1992). In the authors' experience, all subjects administered this dose experience cognitive impairment. The timing of the scans was based on prior studies showing that the amnestic effects of IV scopolamine occur to a consistent degree 60 to 150 minutes after administration (Sunderland et al. 1987; Kopelman and Corn 1988; Molchan et al. 1992).

Twenty-one slices were acquired during each of the two scans, starting at $5 \mathrm{~mm}$ above the plane parallel to the canthomeatal (CM) line. The interslice interval was approximately $3.5 \mathrm{~mm}$.

\section{Regions of Interest Analysis}

Sixty regions of interest (ROI) were measured in five standard transaxial planes (Figure 2) (plane A, $94 \mathrm{~mm}$ above the $C M$ line; plane $B, 81 \mathrm{~mm}$ above the $C M$ line; plane $C, 67 \mathrm{~mm}$ above the CM line; plane $D, 53 \mathrm{~mm}$ above the $\mathrm{CM}$ line; and plane $\mathrm{E}, 40 \mathrm{~mm}$ above the $\mathrm{CM}$ line) by a staff member experienced in the technique and blind to subject identity and drug condition. Since 


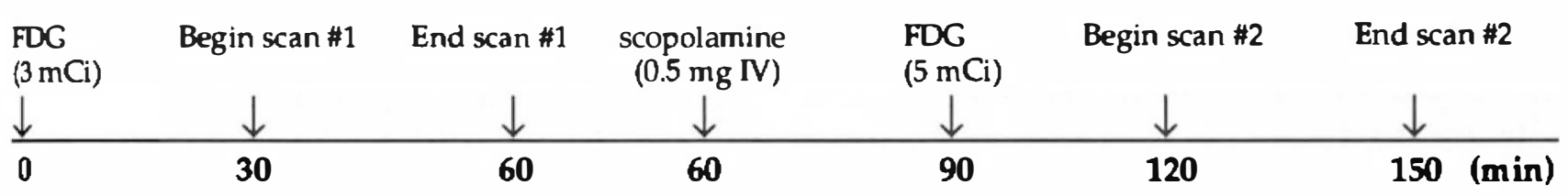

Figure 1. Study design.

the double FDG procedure eliminates repositioning the head for each scan, the five planes selected in the first scan were matched exactly to the same slices or images in the second scan. ROIs were primarily from cortical areas, although ROIs which included the thalamus (D plane), basal ganglia (D plane), hippocampus (E plane), and cingulate gyrus (B plane) were also sampled.

ROIs, which were $7 \mathrm{~mm} \times 7 \mathrm{~mm}$ boxes, were placed in a semi-automated procedure through neuroanatomical matching to a standard PET template based on the brain atlas of Matsui and Hirano (1978), as has been previously described (Clark et al. 1985; Cohen et al. 1988). Prior studies have shown that the interater reliability of this method of choosing ROIs is very high $(r>0.95)$ (Semple et al. 1993).

Raw pixel values were converted to glucose metabolic rates in milligrams of glucose per $100 \mathrm{~g}$ of tissue per minute (Brooks 1982). Metabolic rates are expressed as global glucose metabolic rates (estimates of the average value for glucose metabolism obtained from all the gray-matter-rich areas of the brain sampled), absolute regional glucose metabolic rates (average values for glucose metabolism obtained from the region of interest), and normalized regional glucose metabolic rates (regional absolute metabolism rate/global metabolism rate). The normalization procedure was used to minimize the effects of individual variation in global metabolism on regional metabolism (Bartlett et al. 1988).

\section{Statistics}

Comparisons of global and regional metabolic rates between off- and on-drug scans were done using both absolute and normalized values. The analyses were performed using paired $t$-tests (two-tailed). In view of the exploratory purpose of the study and the small number of subjects, we chose to decrease the probability of Type II errors by omitting corrections for multiple comparisons. Although our hypotheses about metabolic changes after scopolamine could be limited to brain regions reported in previous PET studies, we felt that it would be more appropriate in our initial study in older adults to take advantage of the ability of PET to image large areas of the brain simultaneously.
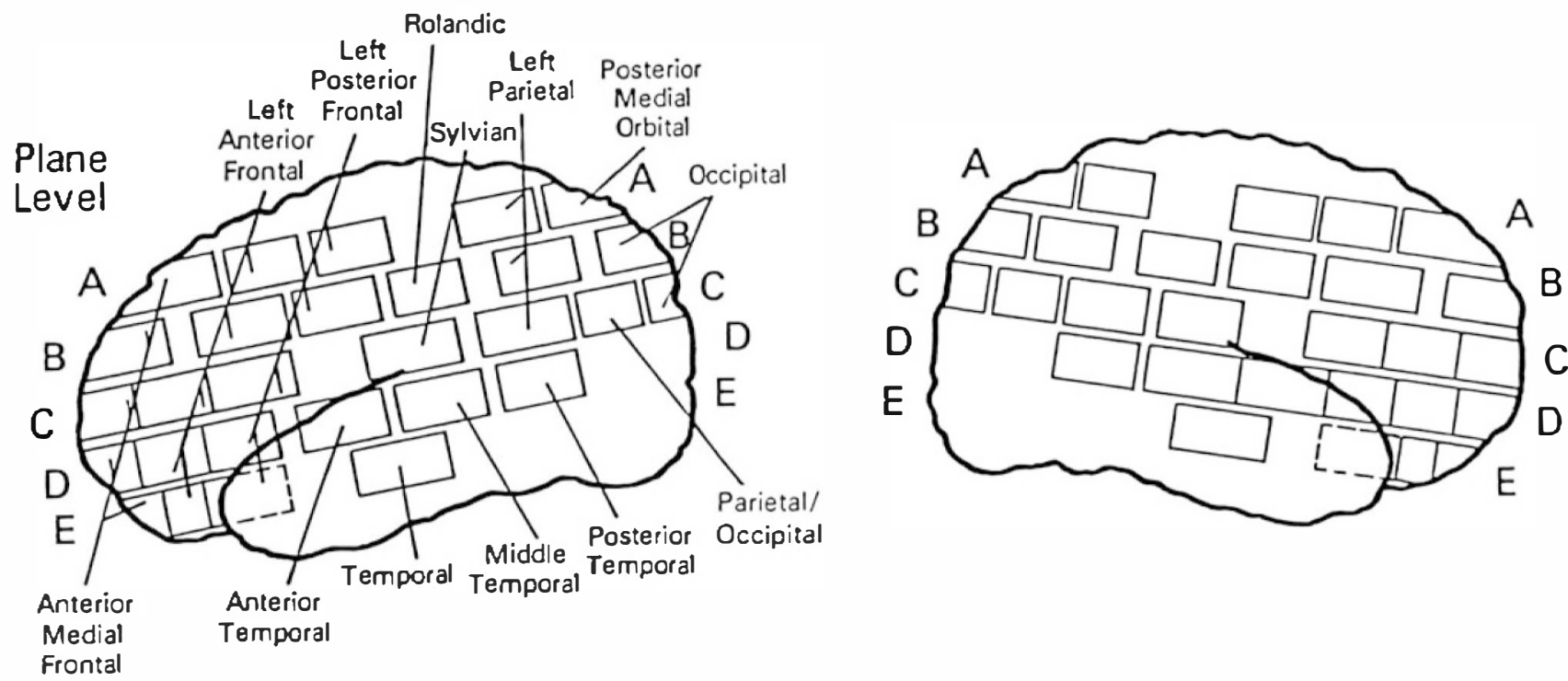

Figure 2. Schematic representation of the regions of interest (ROIs) sampled in the left and right hemispheres. Regions labeled as medial, although sampled from the medial portion of the cortex, are represented when possible as incomplete boxes on the lateral surface of each hemisphere. Additional ROIs not pictured are left and right thalamus, caudate (head area), putamen (anterior and posterior regions), hippocampus, and the mid-cingulate region. Total number of ROIs is 60. 


\section{RESULTS}

\section{Global and Absolute Regional Cerebral Glucose Metabolism}

Data are summarized in Figure 3. There was no significant change in global metabolic rate after scopolamine $(7.41 \pm 0.58$ off-drug vs. $7.39 \pm 0.95 \mathrm{mg}$ glucose/100 g tissue/min on-drug). In six of the 60 ROIs a significant change in absolute regional glucose metabolism was detected. Decreased regional glucose metabolic rates were detected in three ROIs, two in prefrontal areas and one in occipital cortex. Increased metabolic rates occurred in left and right parietoccipital ROIs and a left middle temporal lobe ROI.

\section{Normalized Regional Cerebral Glucose Metabolism}

Data are summarized in Figure 4. Changes were similar to the absolute data, with the exception of one of the prefrontal ROIs in which the change did not reach statistical significance.

\section{Side Effects of Scopolamine}

All subjects reported experiencing dry mouth after scopolamine administration. Six subjects experienced motor restlessness, manifested by leg movements; eight subjects were drowsy, and one was lightheaded. Side effects usually began within 15 minutes of injection and lasted throughout the procedure.

\section{DISCUSSION}

Using a double FDG/PET paradigm, we found that scopolamine significantly altered regional cerebral glucose metabolism in a number of brain areas in normal older volunteers. The decreased metabolic rates we observed in prefrontal cortex may relate to the inattentiveness and decreased ability to suppress inappropriate responses typical of AD (Fuld et al. 1982) and reported in normal subjects following scopolamine administration (Drachman and Leavitt 1974; Dunne and Hartley 1985; Broks et al. 1988). The decrease in metabolic rate after scopolamine in an area of the occipital cortex that includes primary visual cortex is consistent

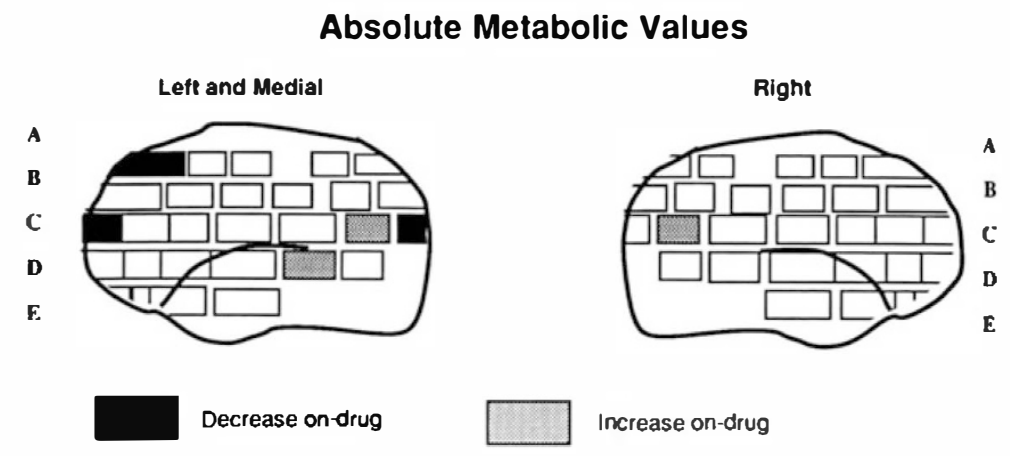

Figure 3. Regions of the brain where glucose metabolism (absolute values) changed after scopolamine administration. The abbreviation ant. = anterior.

\begin{tabular}{lllll} 
Region & Off-drug & On-drug & $p$ & $\%$ Change \\
\hline $\begin{array}{l}\text { A plane - } \\
\text { ant. medial frontal }\end{array}$ & $9.30 \pm 0.98^{*}$ & $8.67 \pm 1.53$ & 0.04 & -6.8 \\
& & & & \\
$\begin{array}{l}\text { C plane - } \\
\text { ant. medial frontal }\end{array}$ & $8.99 \pm 1.36$ & $8.28 \pm 1.67$ & 0.05 & -7.9 \\
$\begin{array}{l}\text { occipital } \\
\text { left parietal/occipital }\end{array}$ & $8.63 \pm 1.37$ & $9.65 \pm 1.63$ & 0.001 & -9.6 \\
right parietal/occipital & $8.99 \pm 0.95$ & $9.16 \pm 1.31$ & 0.01 & +7.4 \\
& & $9.71 \pm 1.54$ & 0.04 & +8.0 \\
$\begin{array}{l}\text { D plane - } \\
\text { left middle temporal }\end{array}$ & $9.40 \pm 1.03$ & $9.99 \pm 1.37$ & 0.03 & +6.3 \\
& & & &
\end{tabular}


with findings of others and with the presence of a fairly high concentration of muscarinic receptors in that region (Frey et al. 1992; Cohen et al. submitted). It is also consistent with scopolamine's effects on the visual evoked potential (Smith et al. 1990).

Increased metabolic rates after scopolamine in the left and right parietoccipital ROIs and a left middle temporal cortex ROI were unexpected. The parietoccipital ROIs are probably association areas, having to do with visual-spatial functions. The middle temporal lobe ROI probably includes auditory association cortex and primary auditory cortex. As one explanation, perhaps the increases are secondary to a disinhibitory mechanism on these areas, through other areas of the brain whose function was suppressed by scopolamine. Possibly, some areas with decreased metabolic rates may not be detected, especially in aged brains, in which CBF and metabolic rates have been reported to be already reduced in limbic and association cortices (Kuhl et al. 1982; Martin et al. 1991), although other studies indicate no alterations in these measures with age (Duara et al. 1984). If metabolic rates in aged brain are relatively reduced in these brain areas because of decreased numbers of neurons or any other reason, perhaps further challenge with scopolamine may not produce a detectable change.

The most consistent abnormalities found with PET in $\mathrm{AD}$ patients are decreased metabolic rates in association cortices, especially parietotemporal (Frackowiak et al. 1981; Foster et al. 1984; Duara et al. 1986; Haxby et al. 1988), with frontal decreases more evident as the illness progresses (Frackowiak et al. 1981; Haxby et al. 1988; Friedland et al. 1989). Significant decreases in regional glucose metabolic rate in occipital cortex have also been reported (Foster et al. 1984; Friedland et al. 1989). Whether the blood flow/metabolic changes detected by PET are related to the muscarinic system deficit in AD patients is unknown. The decreased metabolic rates after scopolamine we found in prefrontal and occipital cortices are consistent with metabolic changes seen in AD brain, but the increased rates in parietoccipital and temporal lobe ROIs are not.

Three prior neuroimaging studies have examined the effects of scopolamine in humans. The first report used the ${ }^{133} \mathrm{Xe}$ inhalation technique in 15 young normal volunteers and found that global $C B F$, predominantly frontal lobe regional $\mathrm{CBF}$, was reduced after scopolamine administration (Honer et al. 1988). Using
Normalized Metabolic Values
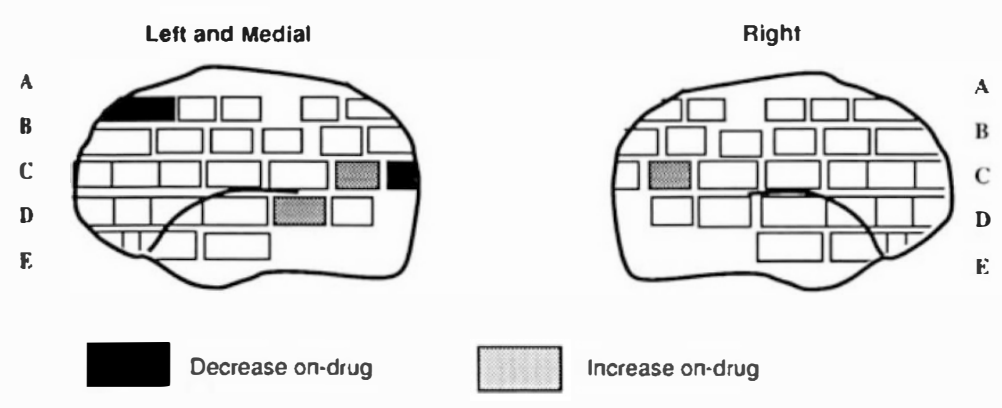

Increase on-drug
Brain regions where glucose metabolism changed in response to scopolamine:

\begin{tabular}{|c|c|c|c|c|}
\hline Region & Of & On-drug & $p$ & $\%$ Change \\
\hline $\begin{array}{l}\text { A plane - } \\
\text { ant. medial fr }\end{array}$ & $0.97 \pm 010^{*}$ & $0.91 \pm 0.12$ & 0.003 & -6.2 \\
\hline $\begin{array}{l}\text { C plane - } \\
\text { occipital } \\
\text { left } \\
\text { right parietal/occipital }\end{array}$ & $\begin{array}{l}1.11 \pm 0.07 \\
0.89 \pm 0.09 \\
0.93 \pm 0.09\end{array}$ & $\begin{array}{l}1.01 \pm 0.09 \\
0.96 \pm 0.08 \\
1.02 \pm 0.10\end{array}$ & $\begin{array}{l}0.003 \\
0.005 \\
0.01\end{array}$ & $\begin{array}{l}-9.0 \\
+7.9 \\
+9.7\end{array}$ \\
\hline $\begin{array}{l}\text { D plane - } \\
\text { left }\end{array}$ & $0.98 \pm 0.07$ & $1.05 \pm 0.06$ & 0.01 & +7.1 \\
\hline
\end{tabular}

${ }^{*}$ means $\pm S D$

\section{middle temporal}

Figure 4. Regions of the brain where glucose metabolism (normalized values) changed after scopolamine administration. 
the same technique in seven elderly normal volunteers, Gitelman and Prohovnik (1992) found that after combined administration of scopolamine and the nicotinic antagonist mecamylamine, $\mathrm{CBF}$ was similarly reduced in frontal cortex. They also reported a decrease in parietotemporal cortex, similar to that found in $A D$, indicating that the combination of these two drugs replicated the CBF alterations reported in AD better than scopolamine alone. These findings are consistent with the known muscarinic (Bartus et al., 1982; Whitehouse et al., 1982) and nicotinic (Whitehouse et al., 1988) deficits in the illness. In another study, a group of young normal volunteers who had not received scopolamine were compared with a group who received $0.5 \mathrm{mg}$ IV in a FDG/PET study. Decreased metabolic rates were noted in the thalamus, occipital, right frontoparietal, and cingulate cortices; increased metabolic rates were noted in the basal ganglia (Cohen et al. submitted). This study differed from the current one in a number of ways. Most notably, young normal volunteers were studied, and subjects performed a continuous performance task during the scans. Alterations in the cholinergic system have been reported to occur with age that may alter the response to scopolamine in aged subjects (Molchan et al. 1992). These age-related central cholinergic system changes include decreased acetylcholine synthesis and release (Decker 1987), as well as decreases in muscarinic receptor numbers (Nordberg and Winblad 1981; Rinne 1987).

In animal studies, scopolamine generally has been shown to decrease glucose metabolism in hippocampus and cortical areas, basal ganglia, and thalamus (Weinberger et al. 1979; Dam and London 1984; Helen and London 1984; Piercey et al. 1987; Ray et al. 1992), and cholinergic agonists, both muscarinic and nicotinic, to enhance glucose metabolism (Dam and London 1984; Harrell and Davis 1985; Soncrant et al. 1985; Hoffman et al. 1986; Churchill et al. 1987; London et al. 1988). Similarly, lesions of the nucleus basalis magnocellular $(\mathrm{nbM})$ in animals, which is homologous to the nucleus basalis of Meynert in humans (the source of the cholinergic projection to cortex), results in decreased cerebral glucose metabolism, especially in frontal cortical regions (Lamarca and Fibiger 1984; London et al. 1984; Kiyosawa et al. 1989; Mihara 1989).

In one study of baboons given a left nbM lesion, cortical metabolic rate of glucose was suppressed in the ipsilateral cortex, with the greatest decrease in frontotemporal regions. These decreases correlated with decreases in choline acetyltransferase activity, indicating that cortical cholinergic differentiation had a role in the metabolic changes (Kiyosawa et al. 1989). It is not clear why some cortical regions, in this and prior studies, should have decreased metabolic rates relative to other cortical regions, as the distribution of muscarinic receptors throughout the cortex is relatively con- sistent throughout the cortical lobes, with slightly higher binding in temporal cortex according to some studies (Lang and Henke 1983; Cortes et al. 1987). Perhaps receptor subtypes, which have different affinities for scopolamine, contribute to decreased metabolic rates in some areas but not others (Bonner et al. 1988). Using $\left[{ }^{11} \mathrm{C}\right]$ scopolamine and PET to image muscarinic receptors in six young normal volunteers, Frey and colleagues found that the highest specific binding occurred in the basal ganglia and cerebral cortex (Frey et al. 1992), consistent with in vitro autoradiographic studies of human brain (Enna et al. 1977; Davies and Verth 1978; Lang and Henke 1983; Cortes et al. 1986; Lin et al. 1986; Cortes et al. 1987).

In summary, the alterations in regional glucose metabolic rates that we found in older volunteers using a double injection method of FDG administration with PET are consistent with some, but not all of the changes found in the brains of patients with AD. This may be due to the involvement in the disease of neurotransmitter systems besides the muscarinic cholinergic, which scopolamine targets, or to involvement of other pathological lesions such as amyloid plaques in areas of decreased metabolic rates (Honer et al. 1988). Also, five different muscarinic receptor subtypes have been identified using molecular biological techniques to date (Bonner et al. 1988). Future studies utilizing ligands specific to each subtype, when they become available, will enhance understanding of changes that occur in the aging brain and in dementia.

\section{ACKNOWLEDGMENTS}

The authors would like to acknowledge the assistance of Glinda Fitzgerald and Laura Liebenauer, Drs. Barry Horwitz and Jose Maisog for writing the subtraction program, Wilma Davis for assistance with the references, and the PET technicians of the Department of Nuclear Medicine, NIH.

\section{REFERENCES}

Bartlett EJ, Brodie JD, Wolf AP, Christman DR, LaskaE, Meissner M (1988): Reproducibility of cerebral glucose metabolic measurements in resting human subjects. J Cereb Blood Flow Metab 8:502-512

Bartus RT, Dean RL, Beer B, Lippa AS (1982): The cholinergic hypothesis of geriatric memory dysfunction. Science 217:408-417

Bonner TI, Young AC, Brann MR, Buckley NJ (1988): Cloning and expression of the human and rat $\mathrm{m} 5$ muscarinic acetylcholine receptor genes. Neuron 1:403-410

Broks P, Preston GC, Traub M, Poppleton P, Ward C, Stahl SM (1988): Modelling dementia: Effects of scopolamine on memory and attention. Neuropsychologia 16:685-700

Brooks R (1982): Alternative formula for glucose utilization using labeled deoxyglucose. J Nucl Med 23:538-539 
Brooks RA, DiChiro G, Zukerberg BW, Bairamian D, Larson SM (1987): Test-retest studies of cerebral glucose metabolism using fluorine-18 deoxyglucose: Validation of method. J Nucl Med 28:53-59

Chang JY, Duara R, Barker W, Apicella A, Finn R (1987): Two behavioral states studies in a single PET/FDG procedure: Theory, method, and preliminary results. J Nucl Med 28:852-860

Churchill L, Pazdernik TL, Cross RS, Giesler MP, Nelson SR, Samson FE (1987): Cholinergic systems influence local cerebral glucose use in specific anatomical areas: diisopropyl phosphorofluoridate versus soman. Neuroscience 20:329-339

Clark C, Carson R, Kessler R, Margolin R, Buchsbaum M, DeLisi L, King C, Cohen R (1985): Alternative statistical models for the examination of clinical positron emission tomography/fluorodeoxyglucose data. J Cereb Blood Flow Metab 5:142-150

Cohen RM, Semple WE, Gross M, Holcomb HH, Dowling MS, Nordahl TE (1988): Functional localization of sustained attention: Comparison to sensory stimulation in the absence of instruction. Neuropsychiatry, Neuropsychology, Behav Neurol 1:3-20

Cohen RM, Gross M, Semple WE, Nordahl TE, Sunderland $\mathrm{T}$ (submitted): The metabolic brain pattern of young subjects given scopolamine.

Cortes R, Probst A, Tobler H-J, Palacios JM (1986): Muscarinic cholinergic receptor subtypes in the human brain: II. Quantitative autoradiographic studies. Brain Res 362: 239-253

Cortes R, Probst A, Palacios JM (1987): Quantitative light microscopic autoradiographic localization of cholinergic muscarinic receptors in the human brain: Forebrain. Neuroscience 20:65-107

Dam M, London ED (1984): Glucose utilization in the Papez circuit: Effects of oxotremorine and scopolamine. Brain Res:137-144

Davies P, Maloney AJR (1976): Selective loss of central cholinergic neurons in Alzheimer's disease. Lancet ii:1403-1405

Davies P, Verth AH (1978): Regional distribution of muscarinic acetylcholine receptor in normal and Alzheimer's-type dementia brains. Brain Res 138:385-392

Decker MW (1987): The effects of aging on hippocampal and cortical projections of the forebrain cholinergic system. Brain Res Rev 12:423-438

Drachman DA, Leavitt J (1974): Human memory and the cholinergic system. Arch Neurol 30:113-121

Duara R, Grady C, Haxby J, Ingvar D, Sokoloff L, Margolin RA, Manning RG, Cutler NR, Rapoport SI (1984): Human brain glucose utilization and cognitive function in relation to age. Ann Neurol 16:702-713

Duara R, Grady CL, Haxby JV, Dundaram M, Cutler NR, Heston L, Moore A, Schlageter NL, Larson S, Rapoport SI (1986): Positron emission tomography in Alzheimer's disease. Neurology 36:879-887

Dunne MP, Hartley LR (1985): The effects of scopolamine upon verbal memory: Evidence for an attentional hypothesis. Acta Psychol 58:205-217

Enna SJ, Bennet JPJ, Bylund BD (1977): Neurotransmitter receptor binding regional distribution in human brain. J Neurochem 28:233-236

Foster NL, Chase TN, Fedio P, Patronas NJ, Brooks RA, DiChiro G (1983): Alzheimer's disease: Focal cortical changes shown by positron emission tomography. Neurology 33:961-965

Foster NL, Chase TN, Mansi L, Brooks R, Fedio P, Patronas NJ, DiChiro G (1984): Cortical abnormalities in Alzheimer's disease. Ann Neurol 16:649-654

Frackowiak RSJ, Pozzilli C, Legg NJ (1981): Regional cerebral oxygen supply and utilization in dementia. Brain 104: 753-758

Frey KA, Koeppe RA, Mulholland GK, Jewett D, Hichwa R, Ehrenkaufer RLE, Carey JE, Wieland DM, Kuhl DE, Agranoff BW (1992): In vivo muscarinic cholinergic receptor imaging in human brain with $\left[{ }^{11} \mathrm{C}\right]$ scopolamine and positron emission tomography. J Cereb Blood Flow Metab 12:147-154

Friedland RP, Jagust WJ, Huesman RH, Koss E, Knittel B, Mathis CA, Ober BA, Mazoyer BM, Budinger TF (1989): Regional cerebral glucose transport and utilization in Alzheimer's disease. Neurology 39:1427-1434

Fuld PA, Katzman R, Davies P, Terry RD (1982): Intrusions as a sign of Alzheimer dementia: Chemical and pathological verification. Ann Neurol 11:155-159

Gitelman DR, Prohovnik I (1992): Muscarinic and nicotinic contributions to cognitive function and cortical blood flow. Neurobiol Aging 13:313-318

Harrell LE, Davis JN (1985): Cholinergic influences on hippocampal glucose metabolism. Neuroscience 15:359-369

Haxby JV, Grady CL, Koss E, Horwitz B, Schapiro M, Friedland RP, Rapoport SI (1988): Heterogeneous anteriorposterior metabolic patterns in dementia of the Alzheimer type. Neurology 38:1853-1863

Helen P, London ED (1984): Muscimol-scopolamine interactions in the rat brain: A study with 2-deoxy-d- $\left[1-{ }^{14} \mathrm{C}\right] \mathrm{glu}-$ cose. J Neurosci 4:1405-1413

Hoffman WE, Albrecht RF, Miletich DJ, Hagen TJ, Cook JM (1986): Cerebrovascular and cerebral metabolic effects of physostigmine, midazolam, and a benzodiazepine antagonist. Anesth Analg 65:639-644

Honer WG, Prohovnik I, Smith G, Lucas LR (1988): Scopolamine reduces frontal cortex perfusion. JCereb Blood Flow Metab 8:635-641

Kiyosawa M, Baron J-C, Hamel E, Pappata S, Buverger D Riche D, Mazoyer B, Naquet R, MacKenzie ET (1989): Time course of effects of unilateral lesions of the nucleus basalis of Meynert on glucose utilization by the cerebral cortex. Brain 112:435-555

Kopelman MD, Corn TH (1988): Cholinergic "blockade" as a model for cholinergic depletion. Brain 111:1079-1110

Kuhl DE, Metter EJ, Riege WH, Phelps ME (1982): Effects of human aging on patterns of local cerebral glucose utilization determined by the $\left[{ }^{18} \mathrm{~F}\right]$ fluorodeoxyglucose method. J Cerebral Blood Flow Metab 2:163-171

Kumar A, Schapiro MB, Grady C, Haxby JV, Wagner E, Salerno JA, Friedland RP, Rapoport SI (1991): Highresolution PET studies in Alzheimer's disease. Neuropsychopharmacology 4:35-46

Lamarca MV, Fibiger HC (1984): Deoxyglucose uptake and 
choline acetyltransferase activity in cerebral cortex following lesions of the nucleus basalis magnocellularis. Brain Res 307:366-369

Lang W, Henke H (1983): Cholinergic receptor binding and autoradiography in brains of non-neurological and senile dementia of Alzheimer-type patients. Brain Res 267:271-280

Lin S-C, Olson KC, Okazaki H, Richelson E (1986): Studies on muscarinic binding sites in human brain identified with $\left[{ }^{3} \mathrm{H}\right]$ pirenzepine. J Neurochem 46:274-279

London ED, McKinney M, Dam M, Ellis A, Coyle JT (1984): Decreased cortical glucose utilization after ibotenate lesion of the rat ventromedial globus pallidus. JCereb Blood Flow Metab 4:381-390

London ED, Connolly RJ, Szikszay M, Wamsley JK, Dam M (1988): Effects of nicotine on local cerebral glucose utilization in the rat. J Neuroscience 8:3920-3928

Martin AJ, Friston KJ, Colebatch JG, Frackowiak RSJ (1991): Decreases in regional cerebral blood flow with normal aging. J Cereb Blood Flow Metab 11:684-689

Matsui T, Hirano A (1978): An atlas of the human brain for computerized tomography. Igaku-Shoin, Tokyo

Mihara B (1989): Effects of lesions in the substantia innominata on active avoidance task and cerebral glucose metabolism. Keio J Med 38:419-431

Molchan SE, Martinez RA, Hill JL, Weingartner HJ, Thompson K, Vitiello B, Sunderland T (1992): Increased cognitive sensitivity to scopolamine with age and a perspective on the scopolamine model. Brain Res Rev 17:215-226

Nordberg A, Winblad B (1981): Cholinergic receptors in human hippocampus - Regional distribution and variance with age. Life Sci 29:1937-1944

Perry EK, Tomlinson BE, Blessed G, Bergmann K, Gibson PH, Perry RH (1978): Correlation of cholinergic abnormalities with senile plaques and mental test scores in senile dementia. Br Med J 2:1457-1459

Phelps ME, Mazziotta JC, Baxter L, Gerner R (1984): Positron emission tomographic study of affective disorders: Problems and strategies. Ann Neurol 15:S149-S156

Piercey MF, Vogelsang GD, Franklin SR, Tang AH (1987): Reversal of scopolamine-induced amnesia and alterations in energy metabolism by the nootropic piracetam: Implications regarding identification of brain structures in- volved in consolidation of memory traves. Brain Res 424:1-9.

Ray CA, Blin J, Chase TN, Piercey MF (1992): Effects of cholinergic agonists on regional brain energy metabolism in the scopolamine-treated rat. Neuropharmacology 31:1193-1199

Rinne JO (1987): Muscarinic and dopaminergic receptors in the aging human brain. Brain Res 404:162-168

Sedvall G, Farde L, Persson A, Wiesel F-A (1986): Imaging of neurotransmitter receptors in the living human brain. Arch Gen Psychiatry 43:995-1005

Semple WE, Johnson JL, Cohen R (1993): Reliability in positron emission tomography. In London, ED (ed) Imaging Drug Action in the Brain, Boca Raton: CRC Press, pp. 297-316

Smith, AT, Early F, Jones GH (1990): Comparison of the effects of Alzheimer's disease, normal aging and scopolamine on human transient visual evoked potentials. Psychopharmacology 102:535-543

Soncrant TT, Holloway HW, Rapoport SI (1985): Arecolineinduced elevations of regional cerebral metabolism in the conscious rat. Brain Res 347:205-216

Sunderland T, Tariot PN, Weingartner H, Murphy DL, Newhouse PA, Mueller EA, Cohen RM (1986): Pharmacologic modelling of Alzheimer's disease. Prog Neuro-Psychopharmacol Biol Psychiatry 10:599-610

Sunderland T, Tariot PN, Cohen RM, Weingartner H, Mueller EA, Murphy DL (1987): Anticholinergic sensitivity in patients with dementia of the Alzheimer type and agematched controls: A dose-response study. Arch Gen Psychiatry 44:418-426

Wechsler D (1987): Wechsler Memory Scale:Revised. San Antonio, TX: Harcourt Brace Jovanovich, Inc.

Weinberger J, Greenberg JH, Waldman MTG, Sylvestro A, Reivich M (1979): The effect of scopolamine on local glucose metabolism in rat brain. Brain Res 177:337-345

Whitehouse PJ, Price DL, Struble RG, Clark AW, Coyle JT, DeLong MR (1982): Alzheimer's disease and senile dementia: Loss of neurons in the basal forebrain. Science 215:1237-1239

Whitehouse PJ, Martino AM, Marcus KA, Zweig RM, Singer DL, Kellar KJ (1988): Reductions in acetylcholine and nicotinic binding in several degenerativediseases. Arch Neurol 45:722-724 